\title{
Synthesis and Crystal Structure of Thiolate-Bridged Dinuclear Platinum(II) Complexes
}

\author{
R. V. Suezov ${ }^{a}$, A. V. Eremin ${ }^{a}$, V. V. Gurzhii ${ }^{b}$, N. L. Medvedskii ${ }^{a}$, and A. N. Belyaev ${ }^{a}$ \\ ${ }^{a}$ St. Petersburg State Institute of Technology, Moskovskii pr. 26, St. Petersburg, 190013 Russia \\ e-mail:fon.wonssdorff@gmail.com \\ ${ }^{b}$ St. Petersburg State University, Universitetskii pr. 26, St. Petersburg, 198504 Russia
}

Received May 29, 2015

\begin{abstract}
Reactions of 2,2'-bipyridine platinum(II) complexes with 2-aminoethanethiol or 2,2'-disulfanediyldi(ethan-1-amine) afforded new complexes $\left[\mathrm{Pt}_{2}(\mu\right.$-aet $\left.)\left(\mu-\mathrm{aetH}^{+}\right)(\mathrm{bpy})_{2}\right]\left(\mathrm{NO}_{3}\right)_{4} \cdot 2 \mathrm{H}_{2} \mathrm{O}$ and $\left[\mathrm{Pt}_{2}(\mu\right.$-aet $)\left(\mu-\mathrm{aetH}^{+}\right)$. (bpy) $\left.)_{2}\right]\left(\mathrm{NO}_{3}\right)_{4} \cdot 5 \mathrm{H}_{2} \mathrm{O}$ and heteronuclear complex catena-[(bpy) Pt( $\mu$-aet) $\left.\mathrm{Ag}\right]\left(\mathrm{NO}_{3}\right)_{2} \cdot 3 \mathrm{H}_{2} \mathrm{O}$ (bpy $=2,2^{\prime}$-bipyridine, aet $=2$-aminoethanethiol). All complexes were characterized by elemental analyses and $\mathrm{X}$-ray diffraction data.
\end{abstract}

Keywords: platinum, dinuclear complexes, thiolate complexes, crystal structure, 2-aminoethanethiol

DOI: $10.1134 / \mathrm{S} 1070363215120221$

In recent time much attention has been focused on reactions of platinum and other $d$-element compounds with thiols, thioamino acids, and biologically active sulfur-containing endogenous compounds. The results of these studies are necessary to understand inactivation of antitumor platinum-containing cytotoxic drugs in vivo [1-5], as well as to design model catalysts responsible for the thiol-disulfide status in the human organism [6-8], imbalance of which [8] could lead to acute and (or) chronic disorders $[9,10]$.

It is known that redox regulation of cellular processes is mediated by thiol groups of cysteine [7] constituting structural units of proteins and some oligopeptides. Among these, a particular role is played by glutathione (GSH, L- $\gamma$-glutamyl-L-cysteinylglycine), is endogenous peptide present in all mammalian cells in considerable concentrations and functioning as regulator [7, 11]. Disturbance of the thiol-disulfide balance, i.e., of the ratio of the oxidized (disulfide, $-\mathrm{S}-\mathrm{S}-$ ) and reduced (thiol, $-\mathrm{SH}$ ) cysteine residues $\left(2 \mathrm{GSH}+\mathrm{Ox} \leftrightarrow \mathrm{GSSG}+2 \mathrm{H}^{+}\right.$, where Ox is an oxidant represented by active oxygen species), may result in oxidative stress [12]. Reversible reduction of disulfide bonds to thiol groups in vivo is controlled by a number of enzymes, including metal-containing ones [7, 9, 10], whose active sites can be simulated by coordination compounds of $d$ elements. On the basis of such compounds, pharmaceutical agents capable of regulating the thiol-disulfide status and thus modulating immune response of the organism as a whole have been developed [13-15].

In keeping with the hard and soft acids and bases principle [16], thiols are soft bases that form strongest bonds in reactions with such soft Lewis acids as Pt(II) and $\mathrm{Pd}(\mathrm{II})$; thiols often behave as bridging ligands in complexes with $\mathrm{Pt}(\mathrm{II})$ and $\mathrm{Pd}(\mathrm{II})$ [17]. Information of the structure of biologically important thiol-containing complexes of $d$-elements may be interesting from the viewpoint of determining possible mechanisms of oxidation of thiol groups in thioamino acids, i.e., most of probable reaction paths and intermediate products.

Herein we report the results of studying the reaction of 2,2'-bipyridine platinum(II) complexes with 2aminoethanethiol (aet) and its oxidized form, cystamine [cyst, 2,2'-disulfanediyldi(ethan-1-amine)]. We isolated and determined crystal structures of the following thiolate platinum complexes: $\left[\mathrm{Pt}_{2}(\mu\right.$-aet $)$. $\left(\mu\right.$-aet $\left.\left.\mathrm{H}^{+}\right)(\text {bpy })_{2}\right]\left(\mathrm{NO}_{3}\right)_{4} \cdot 2 \mathrm{H}_{2} \mathrm{O}(\mathbf{1}),\left[\mathrm{Pt}_{2}(\mu\right.$-aet $)\left(\mu\right.$-aetH $\left.{ }^{+}\right)$. (bpy) $\left.)_{2}\right]\left(\mathrm{NO}_{3}\right)_{4} \cdot 5 \mathrm{H}_{2} \mathrm{O}(2)$, and catena- $[(\mathrm{bpy}) \mathrm{Pt}(\mu$-aet $)$. $\mathrm{Ag}]\left(\mathrm{NO}_{3}\right)_{2} \cdot 3 \mathrm{H}_{2} \mathrm{O}$ (3). Complexes 1-3 were synthesized by reaction of (bpy) $\mathrm{PtCl}_{2}$ with 2-aminoethanethiol or cystamine. (2,2'-Bipyridine)dichloroplatinum(II) (bpy) $\mathrm{PtCl}_{2}$ was preliminarily converted into aquated species (bpy) $\mathrm{Pt}(\mathrm{solv})_{2}\left(\operatorname{solv}=\mathrm{H}_{2} \mathrm{O}, \mathrm{OH}^{-}\right)$ [18] via reaction with silver nitrate at $\mathrm{pH}=3$ (Scheme 1). 
Scheme 1.

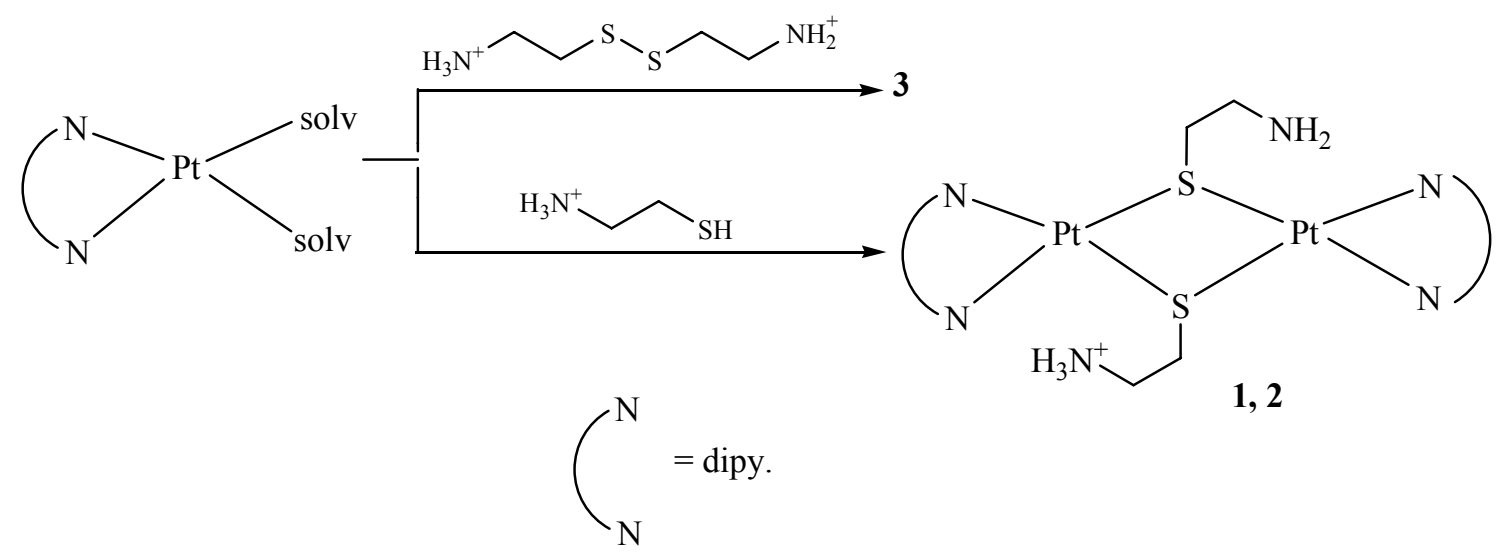

Scheme 2.

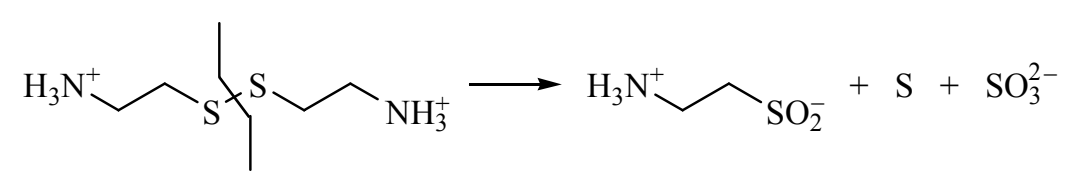

It should be noted that reactions of diammine Pt(II) or Pd(II) with disulfides involving cleavage of the disulfide bond can lead to oligonuclear complexes. For example, cis- $\left[\mathrm{Pd}\left(\mathrm{NH}_{3}\right)_{2} \mathrm{Cl}_{2}\right]$ reacted with cystamine to afford 18-nuclear complex $\left[\mathrm{Pd}_{18}\left(\mu_{3}-\mathrm{S}\right)_{2}(\mu \text {-aet })_{15}\right.$. $\left.\left(\mu-\mathrm{SO}_{2}\left(\mathrm{CH}_{2}\right)_{2} \mathrm{NH}_{2}\right)_{3}\right]\left(\mathrm{NO}_{3}\right)_{7}\left(\mathrm{SO}_{3}\right) \cdot 0.5 \mathrm{H}_{2} \mathrm{O}$; the reaction was accompanied by removal of ammonia molecules from the coordination sphere and partial oxidation of 2-aminoethanethiol [19]. Analogous reactions of cystamine with $\left[\mathrm{Pd}(\right.$ tmen $\left.) \mathrm{Cl}_{2}\right]$ (tmen $=N, N, N^{\prime}, N^{\prime}-$ tetramethylethylenediamine) in acid medium [19] (Scheme 2) and with palladium(II) chloride in aqueous ammonia [20] lead to hexanuclear thiolate-bridged paddle-wheel complexes $\left[\operatorname{Pd}_{2}\left\{\operatorname{Pd}(\text { aet })_{2}\right\}_{4}\right]^{4+}$. As in the preceding case, the ammine ligands were removed completely from the inner coordination sphere, presumably due to strong trans-effect of the thiol [21]. In contrast, palladium(II) complexes with diamines exerting a strong trans-effect, e.g., with aromatic nitrogen containing heterocycles (pyridine, 2,2'-bipyridine, or 1,10-phenanthroline), reacted with both 2aminoethanethiol and cystamine with retention of the ammine ligand, and the products were dinuclear thiolate-bridged complexes such as $\left[\mathrm{Pd}_{2}(\mu \text {-aetH })_{2}\right.$. (phen $\left.)_{2}\right]\left(\mathrm{NO}_{3}\right)_{4} \cdot \mathrm{H}_{2} \mathrm{O}$ [22] and $\left[\mathrm{Pd}_{2}(\mu-\mathrm{Cys})(\mu-\mathrm{CysH}) \cdot\right.$ (bpy $\left.)_{2}\right]\left(\mathrm{NO}_{3}\right)_{3} \cdot 4.5 \mathrm{H}_{2} \mathrm{O}[23]$.

Complexes $\mathbf{1}$ and $\mathbf{2}$ are poorly soluble in water and acetonitrile and almost insoluble in methanol, ethanol, acetone, and diethyl ether. Complex $\mathbf{3}$ is soluble in water and poorly soluble in acetonitrile, acetone, and diethyl ether, and it is readily reduced to the metal with lower alcohols. The crystallographic and structure refinement parameters of complexes $\mathbf{1}-\mathbf{3}$ are given in Table 1.

The platinum atoms in complexes $\mathbf{1}$ and $\mathbf{2}$ have distorted square-planar environment formed by two nitrogen atoms of 2,2'-bipyridine and two sulfur atoms of the bridging 2-aminoethanethiolate ligand (Fig. 1). The average $\mathrm{Pt}-\mathrm{S}$ bond lengths in $\mathbf{1}$ and $\mathbf{2}$ are equal to $\sim 2.3 \AA$ (Table 2), which is consistent with the data for structurally related complexes containing both aliphatic [24] and aromatic [25, 26] ammine ligands. The average $\mathrm{Pt}-\mathrm{N}$ bond length in $\mathbf{1}$ and $\mathbf{2}(\sim 2.03 \AA)$ approaches that in platinum complexes with aromatic amines [25-28]. The $\mathrm{Pt}-\mathrm{N}$ bond in platinum complexes with aliphatic amines (in the trans position with respect to thiolate ligand) is longer (2.3-2.4 $\AA$ ) [24] due to stronger trans-effect of thiols, which is comparable to the trans-effect of aromatic amines [21]. This may favor removal of the amine ligand from the metal coordination sphere [19].

According to Connick et al. [29], dinuclear complexes can be stabilized by weak $\mathrm{M} \cdots \mathrm{M}$ interactions through overlap of the occupied $4 d_{z}^{2}$ and vacant $5 p_{z}$ orbitals of the neighboring metal atoms provided that the distance between these atoms is shorter than $3.5 \AA$ (the Pt $\cdots \mathrm{Pt}$ distance in complexes $\mathbf{1}$ and $\mathbf{2}$ is 3.009 and $3.032 \AA$, respectively). Short $\mathrm{Pt} \cdots \mathrm{Pt}$ distance in a particular dinuclear fragment favors excitation 
Table 1. Crystallographic data and refinement parameters of complexes 1-3

\begin{tabular}{|c|c|c|c|}
\hline Parameter & 1 & 2 & 3 \\
\hline Formula & $\mathrm{C}_{24} \mathrm{H}_{34} \mathrm{~N}_{10} \mathrm{O}_{14} \mathrm{Pt}_{2} \mathrm{~S}_{2}$ & $\mathrm{C}_{24} \mathrm{H}_{40} \mathrm{~N}_{10} \mathrm{O}_{17} \mathrm{Pt}_{2} \mathrm{~S}_{2}$ & $\mathrm{C}_{24} \mathrm{H}_{42} \mathrm{Ag}_{2} \mathrm{~N}_{10} \mathrm{O}_{19} \mathrm{Pt}_{2} \mathrm{~S}_{2}$ \\
\hline Molecular weight & 1140.91 & 1194.96 & 1444.72 \\
\hline Crystal system & Triclinic & Triclinic & Monoclinic \\
\hline Space group & $P 1$ & $P 1$ & $P 2_{1} / n$ \\
\hline$a, \AA$ & $11.9220(10)$ & $11.2773(2)$ & $7.3079(9)$ \\
\hline$b, \AA$ & $12.0394(10)$ & $12.1716(6)$ & $22.197(3)$ \\
\hline$c, \AA$ & $13.4167(11)$ & $14.5554(6)$ & $24.958(3)$ \\
\hline$\alpha, \operatorname{deg}$ & $86.809(2)$ & $73.853(4)$ & 90.00 \\
\hline$\beta, \operatorname{deg}$ & $74.391(2)$ & $82.523(3)$ & $95.807(2)$ \\
\hline$\gamma, \operatorname{deg}$ & $65.046(2)$ & $73.068(3)$ & 90.00 \\
\hline$V, \AA^{3}$ & $1677.9(2)$ & $1833.28(12)$ & $4027.8(8)$ \\
\hline$Z$ & 2 & 2 & 4 \\
\hline$d_{\text {calc }}, \mathrm{g} / \mathrm{cm}^{3}$ & 2.258 & 2.165 & 2.382 \\
\hline$F(000)$ & 1096 & 1156 & 2760 \\
\hline$\mu, \mathrm{mm}^{-1}$ & 8.536 & 7.824 & 8.074 \\
\hline Reflection indices & $\begin{array}{l}-16 \leq h \leq 16 \\
-16 \leq k \leq 16 \\
-15 \leq l \leq 18\end{array}$ & $\begin{array}{l}-14 \leq h \leq 14 \\
-15 \leq k \leq 15 \\
-18 \leq l \leq 18\end{array}$ & $\begin{aligned}-3 & \leq h \leq 11 \\
-29 & \leq k \leq 33 \\
-37 & \leq l \leq 35\end{aligned}$ \\
\hline $2 \theta_{\max }, \operatorname{deg}$ & 30.00 & 27.50 & 32.50 \\
\hline Total/independent reflection number & $9478 / 8721$ & $8404 / 6776$ & $14240 / 10695$ \\
\hline$R_{\text {int }}$ & 0.0647 & 0.0348 & 0.1427 \\
\hline Number of variables & 477 & 536 & 562 \\
\hline$\Delta \rho_{\max }, \Delta \rho_{\min }, \bar{e} / \AA^{3}$ & $-3.717,3.670$ & $-1.118,1.378$ & $-3.294,2.944$ \\
\hline Goodness of fit & 1.040 & 1.030 & 0.988 \\
\hline $\begin{array}{l}R \text { Factors [reflections with } I>2 \sigma(I)] \text { : } \\
R_{1} \\
w R_{2}\end{array}$ & $\begin{array}{l}0.0292 \\
0.0763\end{array}$ & $\begin{array}{l}0.0262 \\
0.0526\end{array}$ & $\begin{array}{l}0.0433 \\
0.0956\end{array}$ \\
\hline $\begin{array}{l}R \text { Factors (all reflections): } \\
R_{1} \\
w R_{2}\end{array}$ & $\begin{array}{l}0.0315 \\
0.0773\end{array}$ & $\begin{array}{l}0.0405 \\
0.0573\end{array}$ & $\begin{array}{l}0.0614 \\
0.1030\end{array}$ \\
\hline
\end{tabular}

involving removal of an electron from the $d \sigma^{*}\left(4 d_{z}^{2}\right)$ orbital of $\mathrm{Pt} \cdots \mathrm{Pt}$ to the bonding $p \sigma\left(5 p_{z}\right)$ orbital; so that the order of the metal-metal bond can be formally regarded as increasing from 0 to $1 / 2$ [29].

On the whole, the molecular structures of complexes $\mathbf{1}$ and $\mathbf{2}$ are similar (Fig. 1), and the bond lengths and bond angles therein coincide within $1 \%$ (Table 2). On the other hand, their crystal structures are essentially different. According to the X-ray diffraction data, unit cells of $\mathbf{1}$ and $\mathbf{2}$ contain two dinuclear cations $\left[\mathrm{Pt}_{2}(\mu \text {-aet })\left(\mu \text {-aetH }{ }^{+}\right)(\text {bpy })_{2}\right]^{4+}$. The number of solvate water molecules influences arrange- ment of platinum atoms in the complexes, as well as non-covalent $\pi-\pi$-stacking interactions [30] between the aromatic bipyridine fragments. The interplanar distance between the bipyridine ligands of the neighboring dinuclear cations $\left[\mathrm{Pt}_{2}(\mu-\mathrm{S}-\mathrm{aet})\left(\mu-\mathrm{S}-\mathrm{aetH}^{+}\right)\right.$. $\left.(\text { bpy })_{2}\right]^{4+}$ is $\sim 3.2174$ and $\sim 3.2416 \AA$ in crystalline complexes $\mathbf{1}$ and $\mathbf{2}$, respectively. The distances between the neighboring cation dimers of complexes $\mathbf{1}$ and 2 also differ insignificantly, $\sim 3.383$ and $3.016 \AA$, respectively (Fig. 2).

The bridging 2-aminoethanethiolate ligands are arranged cis with respect to the $\left[\mathrm{Pt}_{2}(\mu\right.$-aet $)\left(\mu-\mathrm{aetH}^{+}\right)$. 


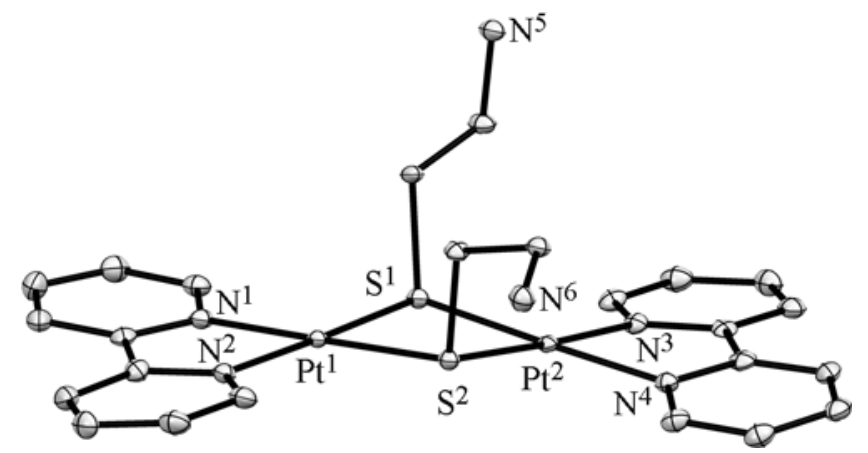

Fig. 1. Structure of the $\left[\mathrm{Pt}_{2}(\mu \text {-aet })\left(\mu \text {-aetH } \mathrm{H}^{+}\right)(\mathrm{bpy})_{2}\right]^{4+}$ cation in complexes $\mathbf{1}$ and $\mathbf{2}$ according to the X-ray diffraction data. Non-hydrogen atoms are shown as thermal vibration ellipsoids with a probability of $50 \%$; hydrogen atoms are not shown.

$\left.(\text { dipy })_{2}\right]^{4+}$ dinuclear cation plane (Fig. 1). This structure allows the cations to form dimers through $\pi-\pi$ stacking between the bipyridine ligands (Fig. 2), and the dimers in turn give rise to 2D layers stabilized by a hydrogen bond system involving the amino nitrogen atoms of the thiolate ligands, crystallization water molecules, and nitrate ions.

The platinum atoms in complex $\mathbf{3}$ have distorted square-planar configuration. The coordination entity is formed by two nitrogen atoms of the bipyridine ligand and nitrogen and sulfur atoms of the thiolate ligand (Fig. 3). 2-Aminoethanthiolate in complex $\mathbf{3}$ is a tetradentate $\mu_{3}$-bridging ligand chelating platinum atom. The average $\mathrm{Pt}-\mathrm{N}_{\text {bpy }}$ distance $(\sim 2.03 \AA$, Table 3$)$ is consistent with the data for structurally related complexes [25-28]. It is interesting that the $\mathrm{Pt}-\mathrm{N}_{\text {aet }}$ bond is short $(2.04 \AA)$, which is more typical of aromatic ammine ligands. Presumably, complex 3 is formed according to a scheme similar to that proposed in $[31,32]$ for the reactions of chelate $\mathrm{Pd}(\mathrm{II}), \mathrm{Ni}(\mathrm{II})$, and $\mathrm{Co}(\mathrm{II})$ complexes with 2 -aminoethanethiol and $\mathrm{Au}^{+}, \mathrm{Ag}^{+}, \mathrm{Pd}^{2+}$, or $\mathrm{Ni}^{2+}$ salts (Scheme 3).

Complex 3 consists of $\left(\mathrm{bpy}-\kappa^{2} N, N^{\prime}\right) \operatorname{Pt}($ aet- $-\kappa S, \kappa N)$ fragments linked by bridging silver atoms to a continuous one-dimensional chain stabilized by $\pi-\pi$ stacking between bipyridine ligands of the neighboring fragments and bridging nitrate ligands (Fig. 3). The average distance between the neighboring bipyridine fragments is 3.44 or $3.46 \AA$ (Fig. 3). The distance between the platinum atoms of the neighboring fragments is fairly long $(\sim 5.1 \AA)$, which hardly allows stabilization of the 1D chain through metal-metal interaction [29].

Thus, the $\left(\mathrm{bpy}-\kappa^{2} N, N^{\prime}\right) \operatorname{Pt}($ aet- $\kappa S, \kappa N)$ units of complex 3 are linked to infinite 1D structure through silver atoms that are coordinated to the thiolate's sulfur atoms and additionally bridged by nitrate ions. The silver atoms occur in distorted tetrahedral or tetragonalpyramidal coordination environment composed of sulfur atoms of the 2-aminoethanethiolate ligands and oxygen atoms of bridging and chelating nitrate ions (Fig. 3). The average $\mathrm{Ag}-\mathrm{O}\left(\mathrm{NO}_{3}^{-}\right)$bond length is $2.53 \AA(2.42-2.67 \AA$, Table 3$)$, which is typical of structurally related compounds [33]. Bridging nitrate
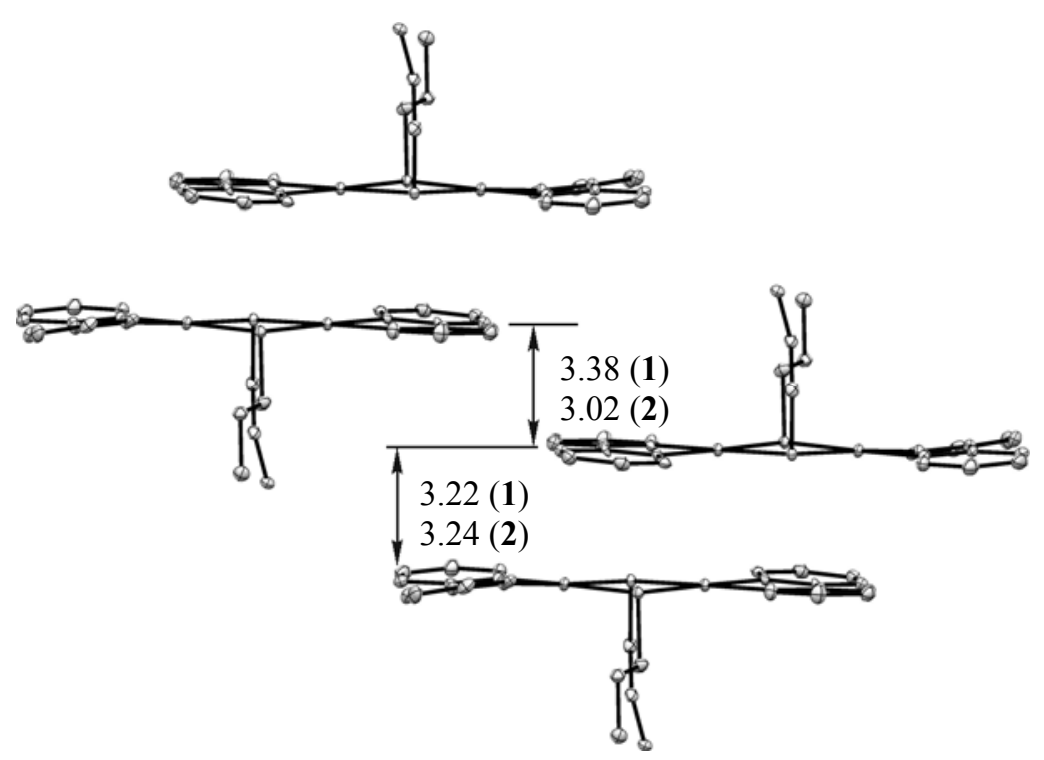

Fig. 2. Crystal packing of complexes 1 and $2 ; \pi-\pi$ stacking interactions $(\AA)$ between the bypiridine ligands in the dimers and between the neighboring dimers are shown; nitrate ions, crystallization water molecules, and hydrogen atoms are omitted. 
Table 2. Principal bond lengths and bond angles in molecules 1 and 2

\begin{tabular}{c|c|c|c}
\hline Bond & $d, \AA$ & Angle & $\tau$, deg \\
\hline $\mathrm{Pt}^{1}-\mathrm{N}^{1}$ & $2.028(1)$ & $\mathrm{N}^{1} \mathrm{Pt}^{1} \mathrm{~N}^{2}$ & $80.46(1)$ \\
& $2.047(2)$ & & $80.10(2)$ \\
$\mathrm{Pt}^{1}-\mathrm{N}^{2}$ & $2.044(1)$ & $\mathrm{S}^{1} \mathrm{Pt}^{1} \mathrm{~S}^{2}$ & $82.04(1)$ \\
& $2.034(2)$ & & $82.41(2)$ \\
& & \\
$\mathrm{Pt}^{1}-\mathrm{S}^{1}$ & $2.288(1)$ & $\mathrm{N}^{3} \mathrm{Pt}^{2} \mathrm{~N}^{4}$ & $80.23(1)$ \\
& $2.304(2)$ & & $80.73(2)$ \\
$\mathrm{Pt}^{1}-\mathrm{S}^{2}$ & $2.298(1)$ & $\mathrm{S}^{1} \mathrm{Pt}^{2} \mathrm{~S}^{2}$ & $81.89(1)$ \\
& $2.299(2)$ & & $82.53(2)$ \\
$\mathrm{Pt}^{2}-\mathrm{N}^{3}$ & $2.044(1)$ & $\mathrm{Pt}^{1} \mathrm{~S}^{1} \mathrm{Pt}^{2}$ & $97.70(1)$ \\
& $2.041(2)$ & & $97.20(2)$ \\
$\mathrm{Pt}^{2}-\mathrm{N}^{4}$ & $2.053(1)$ & $\mathrm{Pt}^{1} \mathrm{~S}^{2} \mathrm{Pt}^{2}$ & $96.68(1)$ \\
& $2.042(2)$ & & $97.74(2)$ \\
$\mathrm{Pt}^{2}-\mathrm{S}^{1}$ & $2.283(1)$ & & \\
& $2.306(2)$ & & \\
$\mathrm{Pt}^{2}-\mathrm{S}^{2}$ & $2.309(1)$ & & \\
& $2.306(2)$ & & \\
\hline
\end{tabular}

ligands link two infinite 1D chains to each other, thus forming a stair motif (Fig. 4). Free $\mathrm{Ag}^{+}$ions were not detected in freshly prepared solutions of $\mathbf{3}$, which indicates high strength of the complex and the existence of large oligonuclear fragments in solution.

\section{EXPERIMENTAL}

The IR spectra (5000-400 $\mathrm{cm}^{-1}$ ) were recorded in $\mathrm{KBr}$ on an FSM-1202 spectrometer (Infraspek) with Fourier transform. The elemental analyses for carbon, nitrogen, and sulfur were obtained on a LECO CHNS(O)932 analyzer. The metal content was determined by reduction of samples in a stream of dry hydrogen at $600-700^{\circ} \mathrm{C}$ and weighting.

The X-ray diffraction data for single crystals of complexes 1-3 were obtained on a Bruker Smart APEX II diffractometer equipped with a twodimensional $\mathrm{CCD}$ detector $\left(\mathrm{Mo} K_{\alpha}\right.$ radiation, $\lambda=$ $0.71073 \AA$; graphite monochromator) at the "Research Center for X-Ray Diffraction Studies" resource center of the St. Petersburg State University. The structures were solved directly and were refined by the fullmatrix least-squares procedure in anisotropic approximation for all non-hydrogen atoms using SHELXL software package [34]. The positions of hydrogen atoms in organic fragments were calculated by SHELX algorithms. The positions of hydrogen atoms in water molecules were determined from the Fourier difference maps and were fixed for the refinement procedure. The X-ray diffraction data for
Table 3. Principal bond lengths and bond angles in molecule 3

\begin{tabular}{c|c||c|c|c|c}
\hline Bond & $d, \AA$ & Bond & $d, \AA$ & Angle & $\tau$, deg \\
\hline $\mathrm{Pt}^{2}-\mathrm{N}^{1}$ & 2.032 & $\mathrm{Ag}^{2}-\mathrm{S}^{1}$ & 2.456 & $\mathrm{~N}^{1} \mathrm{Pt}^{2} \mathrm{~N}^{2}$ & 80.47 \\
$\mathrm{Pt}^{2}-\mathrm{N}^{2}$ & 2.026 & $\mathrm{Ag}^{1}-\mathrm{S}^{1}$ & 2.459 & $\mathrm{~S}^{2} \mathrm{Pt}^{2} \mathrm{~N}^{3}$ & 84.74 \\
$\mathrm{Pt}^{2}-\mathrm{N}^{3}$ & 2.041 & $\mathrm{Ag}^{1}-\mathrm{S}^{2}$ & 2.451 & $\mathrm{~N}^{4} \mathrm{Pt}^{1} \mathrm{~N}^{5}$ & 79.92 \\
$\mathrm{Pt}^{2}-\mathrm{S}^{2}$ & 2.275 & $\mathrm{Ag}^{2}-\mathrm{S}^{2}$ & 2.557 & $\mathrm{~N}^{6} \mathrm{Pt}^{1} \mathrm{~S}^{1}$ & 84.75 \\
$\mathrm{Pt}^{1}-\mathrm{N}^{4}$ & 2.029 & $\mathrm{Ag}^{2}-\mathrm{O}^{1}$ & 2.419 & $\mathrm{~S}^{2} \mathrm{Ag}^{2} \mathrm{~S}^{1}$ & 122.99 \\
$\mathrm{Pt}^{1}-\mathrm{N}^{5}$ & 2.026 & $\mathrm{Ag}^{2}-\mathrm{O}^{6}$ & 2.459 & $\mathrm{Ag}^{2} \mathrm{~S}^{1} \mathrm{Ag}^{1}$ & 94.46 \\
$\mathrm{Pt}^{1}-\mathrm{N}^{6}$ & 2.060 & $\mathrm{Ag}^{1}-\mathrm{O}^{5}$ & 2.605 & $\mathrm{~S}^{1} \mathrm{Ag}^{1} \mathrm{~S}^{2}$ & 135.33 \\
$\mathrm{Pt}^{1}-\mathrm{S}^{1}$ & 2.270 & $\mathrm{Ag}^{1}-\mathrm{O}^{1}$ & 2.672 & $\mathrm{Ag}^{1} \mathrm{~S}^{2} \mathrm{Ag}^{2}$ & 99.42 \\
& & $\mathrm{Ag}^{1}-\mathrm{O}^{2}$ & 2.521 & & \\
& & $\mathrm{Ag}^{2}-\mathrm{O}^{1}$ & 2.419 & & \\
\hline
\end{tabular}

complexes 1-3 were deposited to the Cambridge Crystallographic Data Centre [CCDC entry nos. 1055492 (1), 1055491 (2), and 1055493 (3)].

(2,2'-Bipyridine)dichloroplatinum(II) $\left[\mathrm{Pt}(\right.$ dipy $\left.) \mathrm{Cl}_{2}\right]$ was synthesized as described in [6]. Commercial 2-

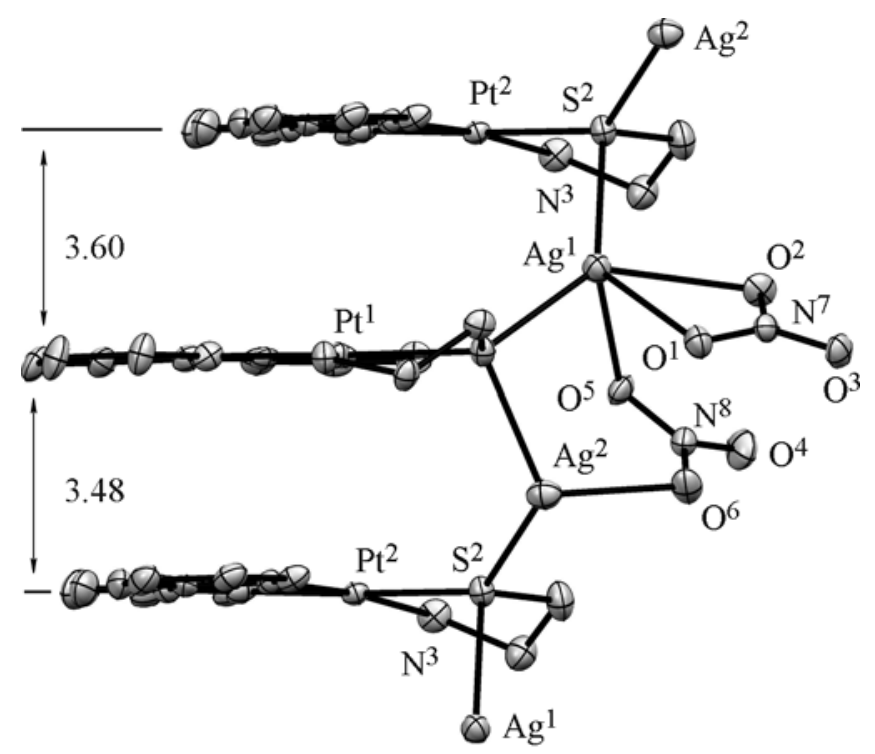

Fig. 3. A fragment of the molecular structure of complex 3 according to the X-ray diffraction data. Non-hydrogen atoms are shown as thermal vibrations ellipsoids with a probability of $50 \%$. $\pi-\pi$ Stacking interactions $(\AA)$ between the bipyridine ligands and coordination modes of nitrate ions are shown. 
Scheme 3.

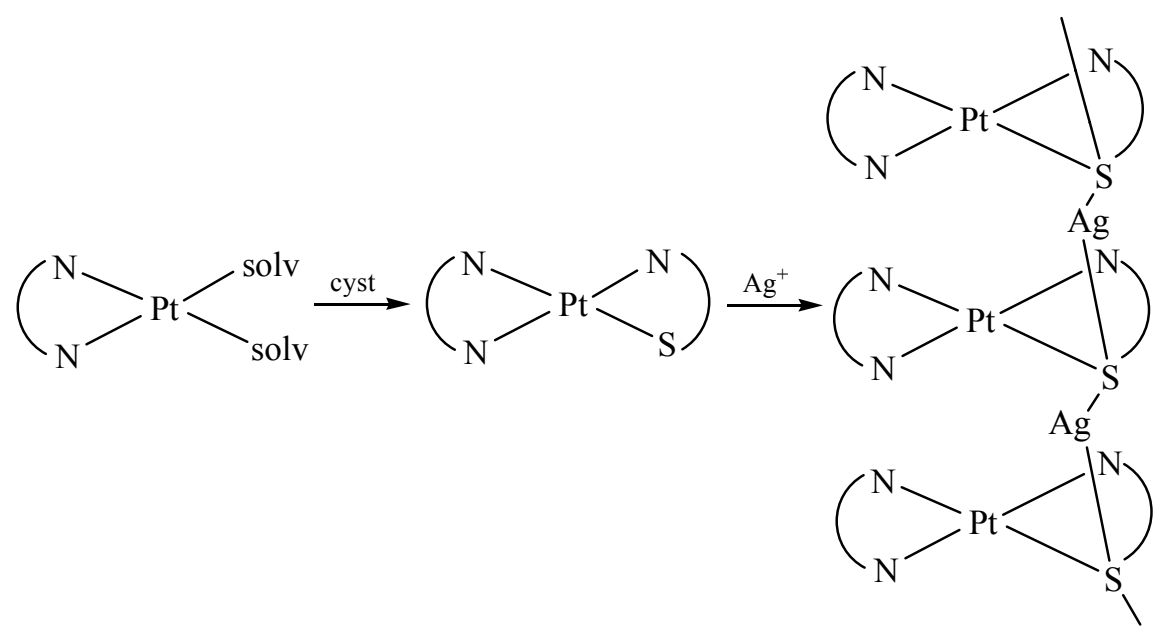

aminoethanethiol hydrochloride (chemically pure grade, Vekton), 2,2'-disulfanediyldi(ethanamine) (analytical grade), silver nitrate (chemically pure grade), and 2,2'-bipyridine (analytical grade) (Neva Reaktiv) were used without additional purification.
Di- $\mu$-(2-aminoethanthiolato)bis [(2,2'-bipyridine) platinum(II)] tetranitrate dihydrate (1) and pentahydrate (2). A solution of $206.4 \mathrm{mg}(1.215 \mathrm{mmol})$ of silver nitrate in $5 \mathrm{~mL}$ of water was added to a suspension of $171.0 \mathrm{mg}(0.405 \mathrm{mmol})$ of $\left[\mathrm{Pt}(\mathrm{bpy}) \mathrm{Cl}_{2}\right]$

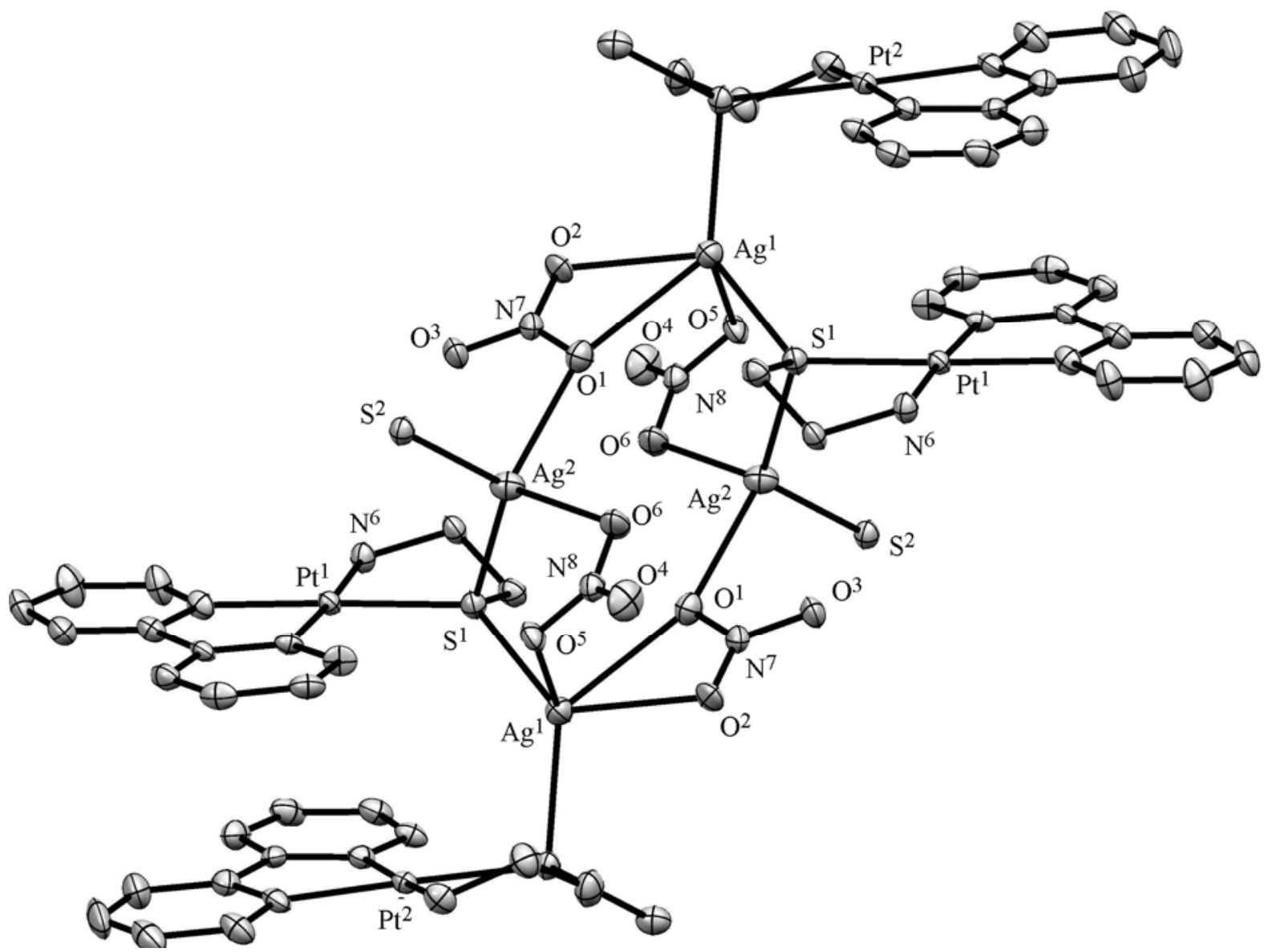

Fig. 4. Crystal packing of complex 3 represented as thermal vibration ellipsoids with a probability of $50 \%$. Solvate water molecules and hydrogen atoms are not shown. 
in $10 \mathrm{~mL}$ of water. The mixture was acidified with $0.5 \mathrm{M}$ nitric acid to $\mathrm{pH} 3$ and heated for $4-5 \mathrm{~h}$ at $70^{\circ} \mathrm{C}$. The precipitate of silver nitrate was filtered off, a solution of $46.0 \mathrm{mg}(0.405 \mathrm{mmol})$ of 2-aminoethanethiol hydrochloride in $5 \mathrm{~mL}$ of water was added to the filtrate, and the mixture was heated for $1 \mathrm{~h}$ at $70^{\circ} \mathrm{C}$. The yellowish flaky solid was filtered off, the filtrate was evaporated on a rotary evaporator to a volume of 5-7 mL, and the residue was left to stand on exposure to air for crystallization of complex 1. Complex 2 crystallized on slow evaporation. Complex 1: yield $\sim 70 \%$. Found, \%: C 25.26; H 2.92; N 12.20; Pt 34.20; S 5.61. $\mathrm{C}_{24} \mathrm{H}_{34} \mathrm{~N}_{10} \mathrm{O}_{14} \mathrm{~S}_{2} \mathrm{Pt}_{2}$. Calculated, \%: C 25.27; $\mathrm{H}$ 3.00; N 12.28; Pt 34.20; S 5.62. Complex 2: yield $\sim 70 \%$. Found, \%: C 24.11; H 3.30; N 11.74; Pt 32.65; S 5.36. $\mathrm{C}_{24} \mathrm{H}_{40} \mathrm{~N}_{10} \mathrm{O}_{17} \mathrm{~S}_{2} \mathrm{Pt}_{2}$. Calculated, \%: C 24.12; $\mathrm{H}$ 3.37; N 11.72; Pt 32.65; S 5.37.

Complex (3). A solution of $323.4 \mathrm{mg}(1.904 \mathrm{mmol})$ of silver nitrate in a minimum volume of water was added to a suspension of $201 \mathrm{mg}(0.476 \mathrm{mmol})$ of $\left[\mathrm{Pt}(\right.$ bpy $\left.) \mathrm{Cl}_{2}\right]$ in $10 \mathrm{~mL}$ of water. The mixture was acidified with dilute $(0.5 \mathrm{M})$ nitric acid to $\mathrm{pH} 3$ and heated for $4-5 \mathrm{~h}$ at $70^{\circ} \mathrm{C}$. The precipitate of silver chloride was filtered off, a solution of $54 \mathrm{mg}$ $(0.238 \mathrm{mmol})$ of cystamine in $10 \mathrm{~mL}$ of water was added to the filtrate, and the mixture was heated for $1 \mathrm{~h}$ at $70^{\circ} \mathrm{C}$. The white flaky solid was filtered off, and the filtrate was evaporated to a volume of $5-7 \mathrm{~mL}$ and left to stand for crystallization to obtain crystals suitable for X-ray analysis. Yield $40 \%$. IR spectrum, $v, \mathrm{~cm}^{-1}$ : 3500 w.br, 3428 w.br, 3123 m, 3078 m, 3052 m, 3041 $\mathrm{m}, 1610 \mathrm{~s}, 1472 \mathrm{~m}, 1452 \mathrm{~m}, 1384$ v.s, 1370 v.s, 1319 v.s, $1161 \mathrm{~m}, 774 \mathrm{~m}, 721 \mathrm{~m}$.

\section{REFERENCES}

1. Kemp, S., Wheate, N.J., Pisani, M.J., and AldrichWright, J.R., J. Med. Chem., 2008, vol. 51, p. 2787. DOI: $10.1021 / \mathrm{jm} 7016072$.

2. Gibson, D., Sheshinski, H., Greenblatt, H.M., Bino, A., and Shoham, G., Met. Med., 1991, vol. 43, p. 605. DOI: 10.1016/0162-0134(91)84576-u.

3. Timerbaev, A.R., Hartinger, C.G., Aleksenko, S.S., and Keppler, B.K., Chem. Rev., 2006, vol. 106, p. 2224. DOI: $10.1021 / \mathrm{cr} 040704 \mathrm{~h}$.

4. Davis, M.S., Berners-Price, S.J., and Hambley, T.W., Inorg. Chem., 2000, vol. 39, p. 5603. DOI: 10.1021/ ic $000847 \mathrm{w}$.

5. Wang, X. and Guo, Z., Anti-Cancer Agents Med. Chem., 2007, vol. 7, p. 19. DOI: 10.2174/187152007779314062.

6. Morgan, G.T. and Burstall, F.H., J. Chem. Soc., 1934, p. 965.

7. Oktyabr'skii, O.N. and Smirnova, G.V., Biokhimiya (Moscow), 2007, vol. 72, no. 2, p. 158.

8. Sokolovskii, V.V., Tioldisul'fidnaya sistema $v$ reaktsii organizma na faktory okruzhayushchei sredy (ThiolDisulfide System in Organism Response to Environmental Factors), St. Petersburg: Nauka, 2008.

9. Fedoroff, N., Ann. Bot., 2006, vol. 98, p. 289. DOI: 10.1093/aob/mcl128.

10. Filomeni, G., Rotilio, G., and Ciriolo, M.R., Biochem. Pharmacol., 2002, vol. 64, p. 1057. DOI: 10.1016/ S0006-2952(02)01176-0.

11. Jordan, P.A. and Gibbins, J.M., Antioxid. Redox Signaling, 2006, vol. 8, p. 312. DOI: 10.1089/ ars.2006.8.312.

12. Zhou, W., Lu, S., Su, Y., Xue, D., Yu, X., Wang, S., Zhang, H., Xu, P., Xie, X., and Liu, R., Free Rad. Biol. Med., 2014, vol. 74, p. 50. DOI: 10.1016/ j.freeradbiomed. 2014.06.013.

13. Easton, D.M., Nijnik, A., Mayer, M.L., and Hancock, R.E., Trends Biotechnol., 2009, vol. 27, p. 582. DOI: 10.1016/ j.tibtech. 2009.07.004

14. RU Patent no. 2417999, 2011; Byull. Izobret., 2011, no. 13.

15. RU Patent no. 2451010, 2012; Byull. Izobret., 2012, no. 14.

16. Basolo, F. and Pearson, R.G., Mechanisms of Inorganic Reactions, NewYork: Wiley, 1967, 2nd ed. Translated under the title Mekhanizmy neorganicheskikh reaktsii, Moscow: Mir, 1972, p. 592.

17. Dance, I.G., Polyhedron Rep., 1986, vol. 5, p. 1037. DOI: $10.1016 / \mathrm{s} 0277-5387(00) 84307-7$.

18. Rosenberg, B., Biochemie, 1978, vol. 60, p. 859. DOI: 10.1016/S0300-9084(78)80570-7.

19. Stepanova, M.A., Cand. Sci. (Chem.) Dissertation, St. Petersburg, 2012.

20. Efimenko, I.A., Gasanov, Kh.I., Gorbunova, Yu.E., Kurbakova, A.P., and Mikhailov, Yu.N., Dokl. Akad. Nauk, 1992, vol. 326, no. 4, p. 654.

21. Grinberg, A.A., Fizicheskaya khimiya kompleksnykh soedinenii (Physical Chemistry of Coordination Compounds), Leningrad: Nauka, 1972.

22. Stepanova, M.A., Vaulina, D.D., Eremin, A.V., and Belyaev, A.N., Izv. Sankt.-Peterb. Gos. Tekhnol. Inst. (Tekh. Univ.), 2012, no. 13 (39), p. 7.

23. Eremin, A.V., Vaulina, D.D., Stepanova, M.A., Antonov, V.G., Belyaev, A.N., and Simanova, S.A., Russ. J. Gen. Chem., 2011, vol. 81, no. 2, p. 194. DOI: $10.1134 /$ S1070363211020046.

24. Capdevila, M., Clegg, W., Gonzalez-Duarte, P., and Mira, I., J. Chem. Soc. Dalton Trans., 1992, p. 173. DOI: 10.1039/DT9920000173. 
25. Mitchell, K.A., Streveler, K.C., and Jensen, C.M., Inorg. Chem., 1993, vol. 32, p. 2608. DOI: 10.1021/ ic00064a001.

26. Mitchell, K.A. and Jensen, C.M., Inorg. Chem., 1995, vol. 34, p. 4441. DOI: 10.1021/ic00121a023.

27. Tzeng, B., Chan, S., Chan, M.C.W., Che, C., Cheung, K.K., and Peng, S., Inorg. Chem., 2001, vol. 40, p. 6699. DOI: 10.1021/ic010891r.

28. Pap, J.S., Benedito, F.L., Bothe, E., Bill, E., George, S.D., Weyhermuller, T., and Wieghardt, K., Inorg. Chem., 2007, vol. 46, p. 4187. DOI: 10.1021/ic070130+.

29. Connick, W.B., Marsh, R.E., Schaefer, W.P., and Gray, H.B., Inorg. Chem., 1997, vol. 36, no. 5, p. 913. DOI: 10.1021/ic961232v.
30. Meyer, A.E., Castellano, R.K., and Diederich, F., Angew. Chem., Int. Ed., 2003, vol. 42, no. 11, p. 1210. DOI: 10.1002/anie. 200390319.

31. Konno, T., Yonenobu, K., Hidaka, J., and Okamoto, K.A., Inorg. Chem., 1994, vol. 33, no. 5, p. 861. DOI: 10.1021/ic00083a006.

32. Konno, T., Angew. Chem., Int. Ed., 2000, vol. 39, no. 22, p. 4098. DOI: 10.1002/1521-3773(20001117) 39:22<4098::AID-ANIE4098>3.0.CO;2-Y.

33. Yoon, I., Seo, J., Lee, J., Park, K., Kim, J.S., Lah, M.S., and Lee, S.S., Inorg. Chem., 2006, vol. 45, p. 3487. DOI: $10.1021 /$ ic060005i.

34. Sheldrick, G.M., Acta Crystallogr., Sect. A, 2008, vol. 64, no. 1, p. 112. DOI: 10.1107/S0108787307043930. 